\title{
Serviks Kanserinin Erken Teşhisi için Çok Katmanlı Sitoloji Küplerinde Çekirdek ve Sitoplazma Bölütlenmesi
}

\author{
Ceren Gülra MELEK¹, Gökhan BİLGİN²
}

1İstanbul Arel Üniversitesi, Mühendislik-Mimarlık Fakültesi, Bilgisayar Mühendisliği Bölümü, 34537, İstanbul

${ }^{2}$ Yıldız Teknik Üniversitesi, Elektrik Elektronik Fakültesi, Bilgisayar Mühendisliği Bölümü, 34220, İstanbul

(Alınış / Received: 28.04.2017, Kabul / Accepted: 22.08.2017, Online Yayınlanma / Published Online: 30.10.2017)

Anahtar Kelimeler Serviks kanseri, Sitoloji, Görüntü bölütleme, Bilgisayar destekli teșhis, Biyomedikal görüntüler
Özet: Dünya genelinde kadınlarda yaygın olarak görülen ve kanser ölümlerinin önde gelen nedenlerinden biri olan serviks kanseri, Pap smear testi sonucunda elde edilen görüntülerdeki hücre sayısı, şekli ve özelliklerinden yararlanılarak teşhis edilir. Pap smear testinin düzenli olarak yapılması ile serviks kanserinin erken teşhisi ya da servikste henüz kansere dönüșmemiş değisşikliklerin saptanması mümkündür. $\mathrm{Bu}$ nedenle, servikal hücrelerin otomatik olarak bölütlenmesi ile test sonuçlarının hızlı ve doğru bir şekilde değerlendirilmesi oldukça önemlidir. $\mathrm{Bu}$ amaçla, Uluslararası Biyomedikal Görüntüleme Sempozyumu (ISBI'2015) kapsamında gerçekleștirilen, "2. Örtüșen Servikal Sitoloji Görüntü Bölütlenmesi Yarışması" tarafından sağlanan gerçek servikal hücre görüntüleri kullanılmıştır. Kullanılan görüntülerden elde edilen farklı veri kümeleri üzerinde kümeleme ve sınıflandırma yöntemleri ile bölütleme işlemi gerçekleştirilerek hücre çekirdeği, hücre sitoplazması ve görüntü arka planı net bir şekilde tespit edilmeye çalışılmıştır. Çalışmanın başarısı farklı servikal sitoloji görüntüleri üzerinde test edilmiștir. Sonuçlar, oluşturulan veri kümelerinin yapılarına ve kullanılan yöntemlere göre incelenmiştir. Bu çalışmanın serviks kanseri ile alakalı ilerideki çalışmalarda bir temel oluşturması temenni edilmektedir.

\section{Nucleus and Cytoplasm Segmentation in Multilayered Cytology Cubes for Early Detection of Cervical Cancer}

\section{Keywords}

Cervical cancer,

Cytology,

Image segmentation,

Computer aided diagnosis, Biomedical images

\begin{abstract}
Cervical cancer, which is one of the leading causes of cancer deaths commonly seen in women worldwide, can be diagnosed by using the number of cells, shapes and characteristics in the images obtained as a result of the Pap smear test. Regular Pap smear testing enables early diagnosis of cervical cancer and the detection of the uncommitted changes in cervix which can be converted into cancer. For this reason, it is very important that the test results are evaluated quickly and correctly by automatically segmenting the cervical cells. For this purpose, real cervical cell images provided by the "2nd Overlapping Cervical Cytology Image Segmentation Competition" which is organized by the International Symposium on Biomedical Imaging (ISBI'2015) are used. Cell nucleus, cell cytoplasm and the background of image have been tried to be determined clearly by performing clustering and classification methods on the different data sets obtained from the used images. The success of the study was tested on different cervical cytology images. The results were examined according to the formation of the data sets and the methods used. It is expected that this study may provide a basis for further studies related to cervical cancer.
\end{abstract}

\section{Giriş}

Serviks kanseri dünya üzerinde kadınlarda en sık görülen kanser türleri arasındadır. 2000 yılında
ABD'de Ulusal Kanser Enstitüsü'nün, Gözetim, Epidemiyoloji ve Bitiş Sonuçları (SEER) araştırmasına göre; serviks kanseri kadınlarda görülen en sık beş kanser türü arasındadır [1]. Türkiye'de de Sağlık 
Bakanlı̆̆ı'nın 1999 yılı verilerinde en sık görülen jinekolojik kanserin serviks kanseri olduğu bildirilmiştir [2]. 2014 yll verilerinde ise serviks kanseri onuncu sıraya kadar gerilemiş ve bu gerilemenin erken teşhis ile sağlandığı belirtilmiştir [3]. Dünya Sağlık Teşkilatı (WHO, World Health Organization)'nın 2012 yılında yayınladığı rapora göre serviks kanseri 2012 yılında az gelişmiş bölgelerde yaşayan kadınlarda, düzenli taramanın yapılamaması nedeniyle en sık görülen ikinci kanser olmuştur [4]. Yapılan bu araştırmalar, serviks kanserinin önlenmesinin ancak erken teşhis ve düzenli tarama ile mümkün olduğunu göstermektedir.

Serviks kanserinin, Pap smear görüntülerinden otomatik olarak teşhis edilebilmesi için bu görüntüler üzerinde hücrelerin tespitine yönelik literatürde çalışmalar mevcuttur. Bu çalışmalarda klasik bölütleme yöntemleri, piksel tabanlı sınıflandırma ya da ikisinin de kullanıldığı melez/hibrit modeller kullanılmıștır. Örnek olarak, hücre çekirdeklerinin bölütlenmesi için alçak geçirgen gürültü giderici filtrenin ardından iteratif eşikleme [5], yıldız şekil öncülleri temelinde yönlü türevler yardımıyla görüntü işleme tabanlı yaklaşımla bölütlenmesi [6], çok-adımlı aşama seviye kümesi yöntemi yaklaşımları kullanılmıştır [7]. Hücre çekirdeği ve sitoplazmasının bölütlenmesi için piksel yoğunluklarına bağlı Gauss karışım modeli çoklu özellik çıkarım yöntemleri kullanılarak uygulanmıștır [8]. Ayrıca, hücre çekirdeği ile sitoplazmasını birbirinden ayırmak için gradyan vektör alanı (GVF) yılan yöntemi [9], hücre kümesi ile görüntü arka planını birbirinden ayırmak için minimum hata eşiklemesi [10] ve şekil-bilimsel geriçatım ve kümeleme yöntemlerinden yararlanılmıştır [11]. İki fazdan oluşan diğer bir çalışmanın ilk fazında parametrik olmayan hiyerarşik bölütleme algoritması ile spektral, şekil ve gradyan bilginin beraber kullanılması, ikinci fazında ise ilk fazda elde edilen bilgilerin ışığında sınıflandırma ile bölütleme işlemi gerçekleştirilmiştir [12]. Çokluölçekli derin evrişimsel ağlar yöntemini kullanan öğrenme tabanlı bir yöntemde, bölütlemedeki örtüşme probleminin üstesinden gelebilmek amacıyla gürbüz önsel şekil özelliklerin kullanılması önerilmiştir [13]. Mikroskobik çoklu örtüşen servikal hücre görüntülerinin otomatik bölütlenmesini öneren diğer bir yöntemde süperpiksel bölütlenmesi ve hücre bilgisi yardımıyla hücre dış hatlarının detaylı tespiti üzerinde çalışılmıştır [14]. Servikal sitoloji görüntülerinde anormal hücrelerin sitoplazma ve çekirdeklerinin bölütlenmesine dair bir çalışmada küresel ve bölgesel çizge kesimleri yöntemi de ele alınmıştır [15]. Yapılan bir diğer çalışmada ise kenar zenginleştirmeli çekirdek ve sitoplazma dış hat detektörü geliştirilerek bölütlemenin nesneler arasında daha sağlıklı bir şekilde gerçekleștirilmesi hedeflenmiştir [16]. Aynı zamanda yarışmanın düzenleyicisi olan yazarların hazırlamış olduğu bir çalışmada örtüşen servikal hücre bölütlemesi amacıyla çoklu seviye kümesi fonksiyonları için geliştirilmiş ortak optimizasyonu üzerinde durulmuştur [17].

Serviks kanseri, Pap smear testi sonucunda elde edilen görüntülerden büyük oranda teşhis edilebilmektedir. Görüntülerdeki çekirdek çevresinin uzunluğu, tahmini sitoplazma alanı, çekirdeksitoplazma alanları oranı, yoğunluk değeri değişiklikleri gibi özelliklerden faydalanılmaktadır. $\mathrm{Bu}$ çalışmada, serviks kanserinin Pap smear görüntülerinden otomatik olarak teşhis edilebilmesi için çok katmalı serviks görüntü küplerinin spektral özelliklerinden yararlanan bir çalışma gerçekleştirilmiştir. Hücre çekirdeği, hücre sitoplazması ve görüntü arka planını birbirinden ayırt edebilmek amacı ile Uluslararası Biyomedikal Görüntüleme Sempozyumu (ISBI'2015) kapsamında gerçekleștirilen, "2. Örtüșen Servikal Sitoloji Görüntü Bölütlenmesi Yarıșması" tarafından sağlanan gerçek servikal hücre görüntüleri kullanılmıştır $[17,18]$. Elde edilen farklı veri kümeleri üzerinde karşılaştırma amacıyla kümeleme yöntemlerinden kortalamalar algoritması ile sinıflandırmaya dayanan bölütleme yöntemlerinden K-en yakın komşuluk (KNN), destek vektör makineleri (SVM) ve rasgele ormanlar (RF), kullanılarak test görüntülerinden elde edilen başarımlar değerlendirilmiştir.

Çalışmanın bundan sonraki kısmında sırasıyla; veri kümesinin elde edilmesi, oluşturulan veri kümesinin özelliklerinin tanıtımı, veri kümesinin eğitilmesi ve bölütlenmesinden oluşan materyal ve metot bölümü; sonrasında, çalışmalardan elde edilen bulguların sunumu ve son olarak da tartışma ve sonuç kısımları okuyuculara sunulmaktadır.

\section{Materyal ve Metot}

$\mathrm{Bu}$ çalışmada, ISBI'2015 konferansı kapsamında gerçekleștirilen "2. Örtüşen Servikal Sitoloji Görüntü Bölütlenmesi Yarışması" tarafından sağlanan çok katmanlı gerçek servikal hücre görüntülerinden alınan spektral özellikler ile eğitim kümeleri oluşturulmuştur. Karşılaştırma amacıyla kümeleme ve sinıflandırma yöntemleri kullanılarak bu veri kümesinden modeller elde edilmiştir. Elde edilen modeller yine gerçek çok katmanlı servikal hücre görüntüleri üzerinde test edilmiştir. Çalışmanın tüm adımları Şekil 1'deki akış şemasında gösterilmiştir.

\subsection{Oluşturulan veri kümelerinin özellikleri}

Yarışma tarafından yayınlanan, örtüşen ve serbest hücrelerin yer aldığı, $1024 \times 1024$ piksellik, her biri yirmi farklı odakla çekilmiş dört adet EDF (Extended Depth of Field) sitoloji görüntüsü kullanılmıştır. Şekil 2'de bu görüntülerden bir tanesinin 6 farklı odakla çekilmiş hali yer almaktadır. Göründügü üzere, farklı odaklarla çekim, görüntüde farklı bölgelerin netleşmesini sağlamaktadır. Her görüntü farklı karşıtlık, doku ve örtüşmeye sahip yaklaşık kırk hücreden oluşmaktadır. Şekil 3'de yapısı gösterilen 
bu katmanlı görüntülerden ikisi eğitim için; test için ise görüntülerin tümü veya sadece test için ayrılmış olan iki adet sitoloji görüntüsü kullanılmıștır.

Kullanılacak veri kümelerini oluşturmak için her bir görüntünün Şekil 3'de gösterildiği gibi 20 katmanlı derinlik görüntüsü üst üste yı̆̆ın haline getirilerek $1024 \times 1024 \times 20$ 'lik bir görüntü küpleri oluşturulmuştur. Veri örnekleri oluşturulan bu küpün her bir katmanındaki yirmi yoğunluk değerinden elde edilmiş olan bir vektör olarak düşünülebilir. Eğitim veri kümesi için hücre çekirdeği, hücre sitoplazması ve görüntü arka planından, Tablo 1'de gösterildiği gibi eşit sayıda, ya da farklı oranlar ve bu oranların katları şeklinde örnekler seçilmiştir. Böylelikle, oluşturulan farklı veri kümeleri ile örneklerin sayısının ve oranlarının sınıflandırma başarısına etkisinin olup olmadığı bu sayede karşılaştırılabilir.

Tablo 1. Veri kümeleri için seçilmiş olan örnek sayıları

\begin{tabular}{ccccc}
\hline $\begin{array}{c}\text { Veri } \\
\text { kümesi }\end{array}$ & $\begin{array}{c}\text { Hücre } \\
\text { çekirdeği }\end{array}$ & $\begin{array}{c}\text { Hücre } \\
\text { sitoplazması }\end{array}$ & $\begin{array}{c}\text { Görüntü } \\
\text { arka } \\
\text { planı }\end{array}$ & $\begin{array}{c}\text { Toplam } \\
\text { örnek } \\
\text { sayısı }\end{array}$ \\
\hline V.K. 1 & 500 & 500 & 500 & 3000 \\
V.K. 2 & 150 & 750 & 1500 & 4800 \\
V.K. 3 & 150 & 450 & 750 & 2700 \\
V.K. 4 & $2 \times 150$ & $2 \times 450$ & $2 \times 750$ & 5400 \\
V.K. 5 & $3 \times 150$ & $3 \times 450$ & $3 \times 750$ & 8100 \\
V.K. 6 & $5 \times 150$ & $5 \times 450$ & $5 \times 750$ & 13500 \\
\hline
\end{tabular}

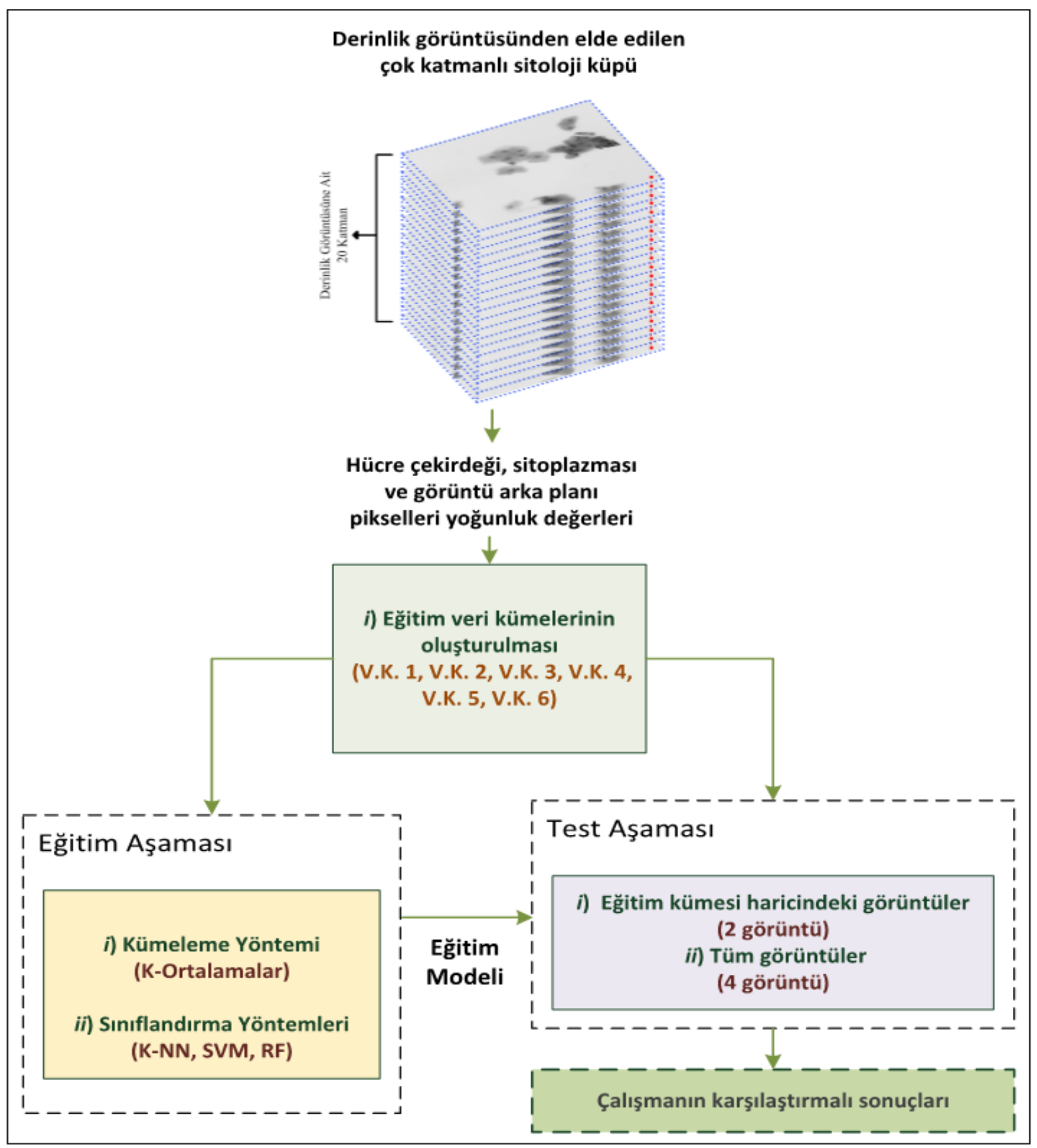

Şekil 1. Çalışmanın akış şeması 


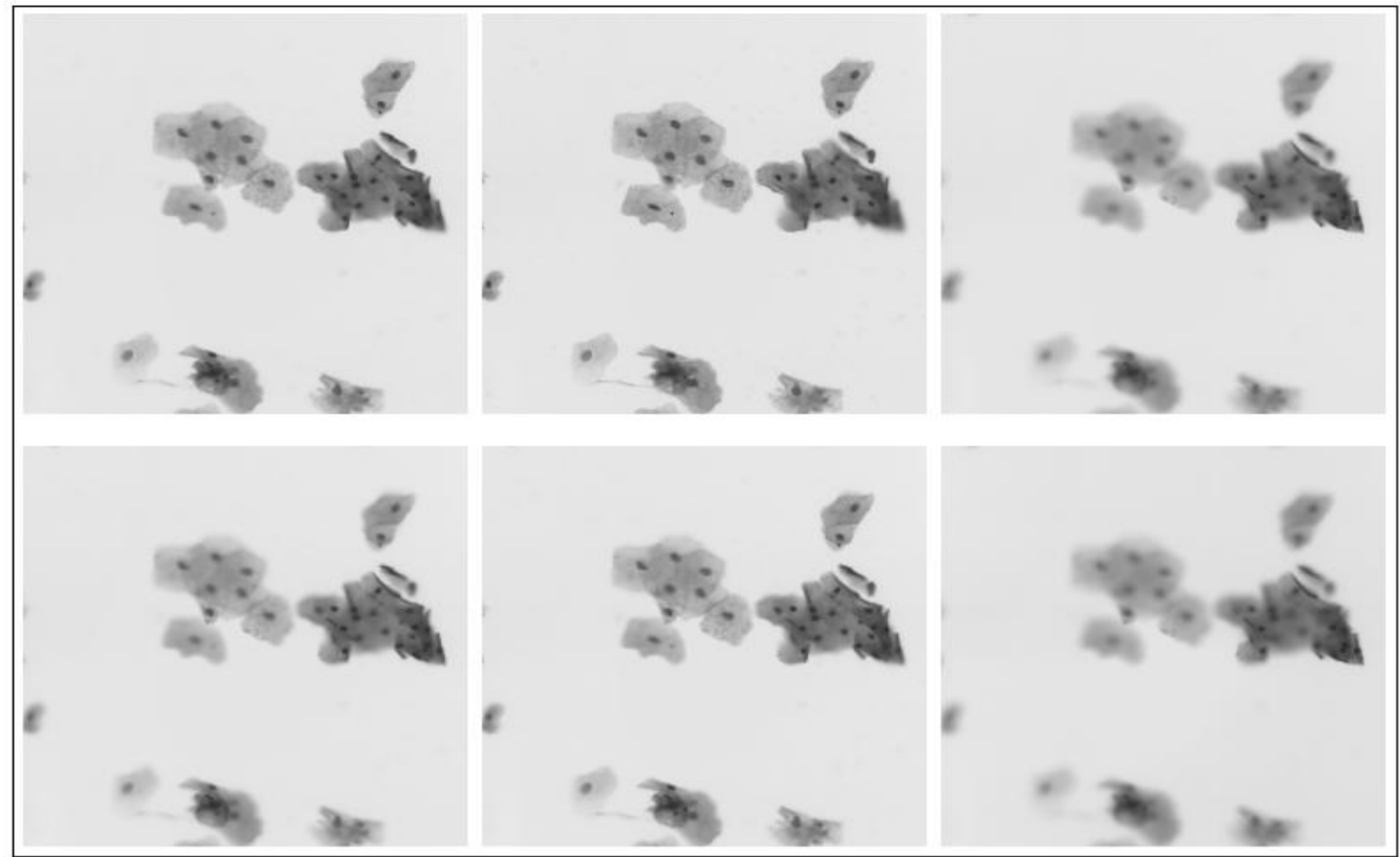

Şekil 2. 6 farklı odakla elde edilen bir sitoloji görüntüsü

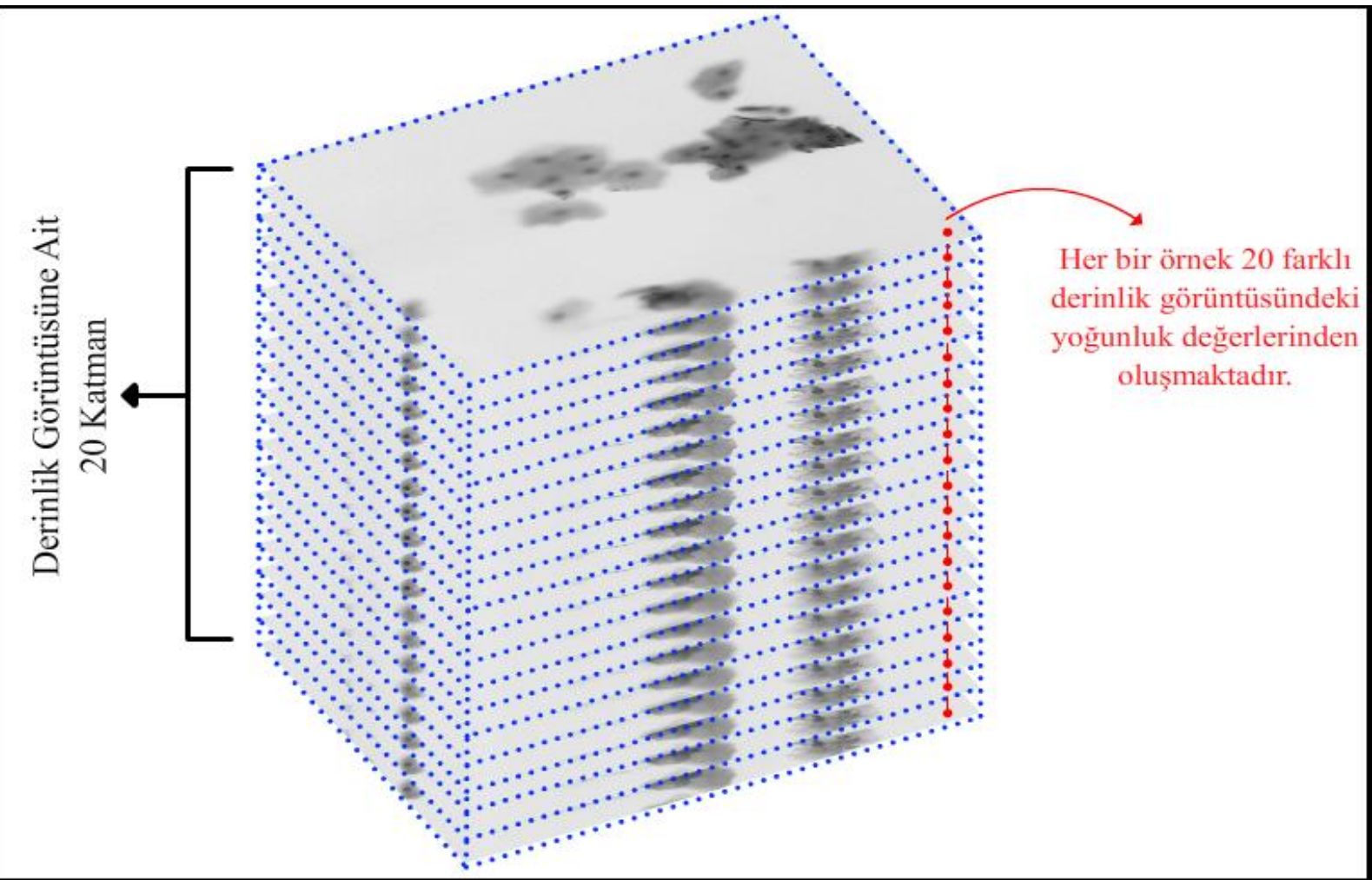

Şekil 3. Çok katmanlı örtüşen hücre görüntülerinden elde edilen görüntü küpü yapısı

Çalışmada, iki farklı test grubu oluşturulmuştur. Birinci grup test kümesi, eğitim kümesi haricindeki iki görüntünün; ikinci grup test kümesi ise tüm görüntülerin yine Șekil 3'deki gibi her pikselinin bir örnek olarak alınması ile oluşturulmuştur. Veri kümesinde çekirdek ve sitoplazma pikselleri için ayrı ayrı yer-gerçekliği (ground-truth) bilgileri yardımıyla test sonuçları yüzdesel olarak elde edilmiştir.

\subsection{Veri kümelerinin eğitilmesi}

$\mathrm{Bu}$ çalıșmada kümeleme yöntemlerinden kortalamalar (k-means) algoritması; sinıflandırma yöntemlerinden ise k-en yakın komşuluk (K-nearest neighbour, KNN), destek vektör makineleri (support vector machines, SVM) ve rasgele ormanlar (random forests) algoritmaları kullanılmıştır. 


\subsubsection{K-Ortalamalar (K-Means)}

Kümeleme algoritmaları verilerin benzerliklerine göre sınıflandırılması ve benzer veriler aynı grupta yer alacak şekilde alt gruplara ayrılması için kullanılmaktadır. Çalışmanın bölütleme aşamasında sonuçları karşılaştırma amacıyla kullanılan kümeleme algoritması k-ortalamalar, literatürde yaygın olarak kullanılan yöntemlerden biridir [15, 16]. K-Ortalamalar yönteminin amacl, d adet değişkenden ve $\mathrm{N}$ adet özellik vektöründen oluşan etiketsiz bir $\mathrm{X}$ veri kümesini önceden belirlenen $\mathrm{C}$ adet kümeye ayırmak ve sinıflandırmaktır [19]. Yöntemin ilk adımı önceden belirlenen $\mathrm{C}$ adet kümenin merkez noktalarının belirlenmesidir. Sonrasında veri kümesindeki her örneğin $\mathrm{C}$ adet küme merkezine olan uzaklığı mesafe ölçütü kullanılarak hesaplanıp, her örnek kendine en yakın olan küme merkezinin bir elemanı olarak atanır. Atama işleminden sonra, küme merkezi her bir küme için yeniden hesaplanır. Tekrar her bir örnek için yeni küme merkezlerine göre atama işlemi yapılır. Bu işlemler, örneklerin atandığı kümelerde bir değişiklik olmadığı yani kümelerin merkez noktalarının sabit kaldığı yere kadar tekrarlanır [19].

$$
J=\sum_{i=1}^{C} \sum_{k=1}^{N} d_{i k}^{2}\left(x_{k}, s_{i}\right)
$$

K-Ortalamalar yönteminde, kümeleme işlemi gerçekleştirilirken denklem (1)'de gösterilen amaç fonksiyonunun en küçük değeri alması sağlanmaya çalışılır. Denklemde C küme sayısını, N örnek sayısını, s küme merkezlerini, d uzaklık ölçütünü ve $x$ özellikleri göstermektedir. Böylece, her bir öznitelik vektörü ile en yakın küme merkezi (centroid) arasındaki en küçük uzaklık ölçütü seçilerek benzer özellik gösteren örneklerin aynı kümede olması sağlanır. Denklemde $d_{i k}^{2}$ ile gösterilen uzaklık ölçütü için denklem (2)'de verilen Öklit uzaklık ölçütü yaygın olarak kullanılmaktadır[19].

$$
d_{i k}^{2}=\left\|x_{k}^{(i)}-s_{i}\right\|^{2}
$$

Çalışmada küme sayısı $(k=3)$ seçilerek dört görüntü veri kümesi üzerinde de hücre çekirdeği, hücre sitoplazması ve görüntü arka planı üç ayrı küme olarak gruplanmıştır. Uzaklık ölçütü olarak da literatürde yaygın olarak kullanılan Öklit uzaklık ölçütü kullanılmıştır.

\subsubsection{K-NN (K-En yakın komşuluk, K-Nearest neighbour)}

K-NN en çok bilinen parametrik olmayan veri temelli bir sınıflandırıcıdır [20]. KNN'nın diğer kümeleme yöntemlerinden en büyük farkı verilerin sınıflandırılması için bir modele ihtiyaç duymaması yani eğitim aşaması olmamasıdır. Test verisindeki örneklerin hangi sınıfa ait olduğuna, sınıflandırmanın yapıldığı anda eğitim veri kümesindeki örnekler ile karşılaştırılması yapılarak karar verilir. Bu yöntem, veriyi kendine en çok benzer özellik gösteren $\mathrm{k}$ tane veride hangi sınıf çoğunlukta ise o sınıfa atar. Buradaki $\mathrm{K}$ değeri kullanıcı tarafından öncelikle belirlenmesi gereken bir değerdir. Verilerin benzerliği Öklit, Manhattan ve Chebyshev uzaklık ölçütleri ile hesaplanır[20].

Çalışmada, eğitim kümesini oluşturmak için seçilen iki görüntüden elde edilen altı farklı veri kümesi $\mathrm{K}=1$ ve $\mathrm{K}=5$ değerleri için $\mathrm{K}$-en yakın komşu yöntemi ile eğitilmiștir. Her bir örnek ile K adet komșu arasındaki benzerliği ölçmek için uzaklık ölçütü olarak literatürde yaygın olarak kullanılan ve denklem (2)’deki gibi Öklit uzaklık ölçütü kullanılmıştır.

\subsubsection{SVM (Karar destek makineleri, Support vector machines)}

SVM'ler çekirdek temelli öğrenme yöntemi olarak veri noktalarını bir çekirdek fonksiyonuyla haritalamak suretiyle yüksek boyutlu bir özellik alanındaki verileri ayırmayı amaçlamaktadır. Örneklerin ikili ayırma problemini çözmek için tanımlanan SVM n-boyutlu özellik vektörü $x_{i}$ ve ikili sinıf etiketi $y_{i}$ ile matematiksel olarak $\left(x_{1}, y_{1}\right),\left(x_{2}, y_{2}\right), \ldots \ldots,\left(x_{N}, y_{N}\right) \in R^{n} X\{ \pm 1\} \quad$ şeklinde ifade edilmektedir. SVM, karar veren eğitim örneklerine (destek vektörleri) en yakın olan en iyi hiper düzlemi bularak farklı sınıfların örnekleri arasında bir karar yüzeyi oluşturur. Bu şekilde, doğrusal olarak ayrılabilir sınıflar için en uygun sınıflandırmayı yapmak mümkündür. Doğrusal olarak ayrılamayan haller içinse SVM'nin çekirdek sürümleri tanımlanmıştır. Çekirdek yaklaşımının temel amacı veriyi yüksek boyutlu uzaya $\left(\phi: R^{n} \rightarrow R^{h}, h>n\right)$ çevirerek tekrar ikili sınıflandırmanın doğrusal olarak elde edilmesini sağlamaktır [22]. SVM, yüksek boyutlu uzayda iç çarpana karşılık gelen bir çekirdek işlevi kullanır. Karar verici destek vektörleri, denklem (3)'ü denklem (4)'e göre maksimize edecek en uygun şekle sokarak bulunabilir.

$$
\begin{gathered}
\sum_{u=1}^{N} \alpha_{u}-\frac{1}{2} \sum_{u=1}^{N} \sum_{v=1}^{N} \alpha_{u} \alpha_{v} y_{u} y_{v} K\left(x_{u}, x_{v}\right), \\
\sum_{u=1}^{N} \alpha_{u} y_{u}=0 \text { and } 0 \leq \alpha_{u} \leq C,
\end{gathered}
$$

Burada, $\mathrm{N}$ eğitim kümesindeki örnek sayısını, $\mathrm{C}$ ceza parametresini, $K\left(x_{u}, x_{v}\right)$ kernel fonksiyonu ve $\alpha$ Lagrange çarpanları katsayılarını göstermektedir. C, daha iyi bir marjin maksimizasyonu sağlamak için yanlıș sınıflandırılmış eğitim örneklerinin sayısını kontrol eder. SVM, dönüşüm fonksiyonunun $(\phi)$ açıkça tanımlanmasını gerektirmese de $K\left(x_{u}, x_{v}\right)=$ $\phi\left(x_{u}\right), \phi\left(x_{v}\right)$ şeklinde yüksek boyutlu uzayda iç çarpım sonucu tanımına dayanmaktadır. Her bir sıfır 
olmayan $\alpha_{u}$ değeri bir destek vektörüne karşılık gelir. Bütün destek vektörleri $\left(N_{S V}\right)$ verildiğinde, herhangi bir $\mathrm{x}$ örneği için doğrusal olmayan sınıflandırma sonucu denklem (5)'deki gibidir.

$$
f=\operatorname{sgn}\left[\sum_{u=1}^{N_{S V}} \alpha_{u} y_{u} K\left(x_{u}, x_{v}\right)+b\right]
$$

Burada $N_{S V}$ destek vektörlerinin sayısını, sgn standart işaret fonsiyonunu göstermektedir. Çok sınıflı problemler birer birer ikili problemlere bölünebilir. M sınıflı bir problem, toplam $m(m-1) / 2$ kadar birebir (one-against-one) SVM'ler hesaplanır ve çoğunluk oyu yöntemi ile karar verilir [23].

Çalışmada, eğitim kümesini oluşturmak için seçilen iki görüntüden elde edilen altı farklı veri kümesi kernel tabanlı birebir SVM yöntemi kullanılarak eğitilmiştir.

\subsubsection{Rastgele ormanlar (Random forest)}

Makine öğrenmesi ve örüntü tanımada yaygın olarak kullanılan ağaç tipi bir topluluk öğrenme algoritması olan RF, tek bir sinıflandırıcı yerine birden fazla sınıflandırıcı ürettikten sonra onların tahminlerinden alınan oylar ile test verisinin sinıflandırılmasını sağlar [24]. RF karar ağacı, veride en iyi başarım gösteren özellikler arasından bulunan düğüm noktalarını dallara ayırma stratejisi yerine, her bir düğümde rastgele alınan özelliklerin en iyisini seçerek bulunan tüm düğümleri dallara ayırır. Bulunan veri kümesi gerçek veri kümesinin farklı versiyonları olarak veri kümesindeki elemanların yer değiştirmesi ile elde edilir. Ağaçlar, rastgele özellik seçimi kullanılarak geliştirilir ve ağaçlar üzerinde herhangi bir budama işlemi yapılmaz [24]. RF algoritmasını başlatmak için kullanıcının belirleyeceği her bir düğümde kullanılan özelliklerin sayısı ve geliştirilecek ağaçların sayısı olmak üzere 2 parametre vardır. Öncelikle, verinin 2/3'ü eğitim örnekleri olarak, geri kalan 1/3'lük kısmı da test örnekleri olarak ayrılır. Sonra her bir eğitim örneğinden budama olmadan en büyük boyutta ağaç geliştirmek için CART (Classification and Regression Tree) algoritması kullanılarak ağaç geliştirilir [25]. Her düğümde tüm niteliklerin var olduğu değerler göz önüne alınarak bölünme işlemi gerçekleştirilir. Bölünme işlemlerinde homojen sınıf dağllımına sahip düğümler tercih edilir. Düğüm homojenliğinin ölçümünde; RF yöntemi, denklem (6)'daki Gini indeksini kullanmaktadır.

$$
\sum \sum_{j \neq i}\left(f\left(C_{i}, T\right) \| T \mid\right)\left(f\left(C_{j}, T\right) \| T \mid\right)
$$

Denklem (6)'da T eğitim veri kümesini, $C_{i}$ rastgele seçilen örneğin sınıfını ve $f\left(C_{i}, T\right) \| T \mid$ ise seçilen örneğin $C_{i}$ sınıfına ait olma olasılığını ifade etmektedir [25]. Temel olarak GINI indeksi azaldıkça sınıf homojenliği artar, tersine GINI indeksi büyüdükçe sınıf homojenliği azalır. Ağaç yapısında bir üstte bulunan düğümün GINI indeksi bir alt düğümün GINI indeksinden büyük olduğunda o dal başarılı kabul edilir. Ağaçtaki her bir yaprak düğümde bir sınıf kaldığında yani GINI indeksi sıfıra ulaşınca ağaç sonlanır. Belirlenen $\mathrm{N}$ adet ağaç üretildiğinde, $\mathrm{N}$ tane ağacın sinıflandırma tahmini sonuçlarına göre yeni örneğin sınıfı belirlenir [25].

Çalışmada, eğitim kümesini oluşturmak için seçilen iki görüntüden elde edilen altı farklı veri kümesi topluluk tabanlı RF sinıflandırma yöntemi kullanılarak eğitilmiştir.

\section{Bulgular}

Çalışmanın bulguları, k-ortalamalar kümeleme algoritmasının sonucu; sinıflandırma tabanlı bölütleme yöntemlerinin sonuçları ve bunların karşılaştırılması kısımlarından oluşmaktadır. Veri kümeleri, kullanılan farklı veri kümeleri ve yöntemlerle eğitildikten sonra farklı test kümeleri üzerinde ayrı ayrı test edilmiştir. K-ortalamalar kümeleme algoritmasının $\mathrm{k}=3$ değeri için dört servikal sitoloji görüntüsünden oluşan veri kümesi üzerinde hücre çekirdeği, hücre sitoplazması ve görüntü arka planı üç ayrı kümeye ayırması sonucunda \%85,73 başarı değeri elde edilmiştir. Kümeleme başarısı düşük bulunduğundan farklı sınıflandırma yöntemleri de uygulanmıştır. Tablo 2 'de ise elde edilen sinıflandırma modellerinin hem tüm görüntüler üzerinde, hem de eğitim kümesi örneklerini içermeyen, harici iki görüntü üzerindeki başarıları gösterilmiştir. Tablo 2'de, her veri kümesinde en yüksek ve en düşük bașarı değerleri tüm veri ve harici test verileri için vurgulanmıştır. Tablo 2'deki sonuçlar, kullanılan sinıflandırma yöntemlerine ve veri kümelerinin oluşturulma şekline göre incelenmiștir. Kullanılan sınıflandırma yöntemlerinin tümü incelendiğinde her veri kümesinde tüm görüntüler test olarak kullanıldığında V.K. 6 haricinde en yüksek başarı oranının RF algoritması olduğu görülmektedir. Eğitim kümesi haricindeki görüntüler üzerinde elde edilen sonuçlarda da RF yine en başarılı yöntem olmakla birlikte V.K. 1 için SVM'nin, V.K. 5 ve V.K. 6 için en başarılı sonucun 5-NN için elde edilmiştir. Elde edilen en düșük bașarı oranının da eğitim kümesi haricindeki ve tüm görüntüler üzerinde elde edilen test sonuçlarına göre 1-NN algoritması için elde edildiği gözlemlenmiştir.

Tablo 3'de kullanılan yöntemlerin performansını ölçmek için tüm veri kümeleri için elde edilen sinıflandırma modellerinin tüm görüntüler üzerindeki kesinlik, duyarlılık ve kappa değerleri verilmiştir. Kesinlik, pozitif olarak etiketlenen örneklerin sayısının pozitif olarak sınıflandırılmış toplam örneklere oranıdır. 
Tablo 2. Farklı eğitim veri kümeleri için elde edilen sınıflandırma modellerinin farklı test veri kümelerindeki test sonuçları

\begin{tabular}{|c|c|c|c|c|c|}
\hline $\begin{array}{c}\text { Veri } \\
\text { kümesi }\end{array}$ & Açıklama & $1-\mathrm{NN}$ & $5-\mathrm{NN}$ & SVM & $\mathrm{RF}$ \\
\hline \multirow{2}{*}{ V.K. 1} & Eğitim kümesi haricindeki görüntüler üzerindeki test sonuçları & $91.76 \%$ & $92.46 \%$ & $93.02 \%$ & $92.77 \%$ \\
\hline & Tüm görüntüler üzerindeki test sonuçları & $92.68 \%$ & $93.43 \%$ & $93.29 \%$ & $93.55 \%$ \\
\hline \multirow{2}{*}{ V.K. 2} & Eğitim kümesi haricindeki görüntüler üzerindeki test sonuçları & $91.67 \%$ & $93.05 \%$ & $92.70 \%$ & $93.12 \%$ \\
\hline & Tüm görüntüler üzerindeki test sonuçları & $92.72 \%$ & $93.28 \%$ & $93.70 \%$ & $94.38 \%$ \\
\hline \multirow{2}{*}{ V.K. 3} & Eğitim kümesi haricindeki görüntüler üzerindeki test sonuçları & $91.58 \%$ & $92.35 \%$ & $92.83 \%$ & $93.17 \%$ \\
\hline & Tüm görüntüler üzerindeki test sonuçları & $92.85 \%$ & $93.78 \%$ & $93.50 \%$ & $94.18 \%$ \\
\hline \multirow{2}{*}{ V.K. 4} & Eğitim kümesi haricindeki görüntüler üzerindeki test sonuçları & $92.10 \%$ & $92.67 \%$ & $92.73 \%$ & $93.06 \%$ \\
\hline & Tüm görüntüler üzerindeki test sonuçları & $93.22 \%$ & $94.05 \%$ & $93.53 \%$ & $94.29 \%$ \\
\hline \multirow{2}{*}{ V.K. 5} & Eğitim kümesi haricindeki görüntüler üzerindeki test sonuçları & $91.69 \%$ & $93.64 \%$ & $92.35 \%$ & $93.08 \%$ \\
\hline & Tüm görüntüler üzerindeki test sonuçları & $93.03 \%$ & $94.25 \%$ & $93.38 \%$ & $94.33 \%$ \\
\hline \multirow{2}{*}{ V.K. 6} & Eğitim kümesi haricindeki görüntüler üzerindeki test sonuçları & $91.86 \%$ & $93.62 \%$ & $92.83 \%$ & $93.10 \%$ \\
\hline & Tüm görüntüler üzerindeki test sonuçları & $\overline{93.14 \%}$ & $94.52 \%$ & $93.68 \%$ & $94.35 \%$ \\
\hline
\end{tabular}

Tablo 3. Farklı eğitim veri kümeleri için elde edilen sinıflandırma modellerinin tüm görüntüler üzerindeki kesinlik, duyarlılık ve kappa değerleri

\begin{tabular}{clccc}
\hline $\begin{array}{c}\text { Veri } \\
\text { Kümesi }\end{array}$ & Yöntem & $\begin{array}{c}\text { Kesinlik } \\
\text { (Precision) }\end{array}$ & $\begin{array}{c}\text { Duyarlılık } \\
\text { (Recall) }\end{array}$ & $\begin{array}{c}\text { Kappa } \\
\text { Değeri }\end{array}$ \\
\hline & 1-NN & 0.941 & 0.927 & 0.810 \\
V.K. 1 & 5-NN & 0.941 & 0.924 & 0.813 \\
& SVM & 0.948 & 0.933 & 0.821 \\
& RF & 0.950 & 0.935 & 0.832 \\
& 1-NN & 0.948 & 0.945 & 0.864 \\
V.K. 2 & 5-NN & 0.944 & 0.931 & 0.820 \\
& SVM & 0.941 & 0.937 & 0.829 \\
& RF & $\underline{\mathbf{0 . 9 6 0}}$ & 0.943 & 0.852 \\
& 1-NN & 0.939 & 0.928 & 0.813 \\
V.K. 3 & 5-NN & 0.949 & 0.937 & 0.838 \\
& SVM & 0.943 & 0.935 & 0.825 \\
& RF & 0.952 & 0.941 & 0.847 \\
& 1-NN & 0.937 & 0.932 & 0.843 \\
V.K. 4 4 & 5-NN & 0.942 & 0.929 & 0.824 \\
& SVM & 0.941 & 0.935 & 0.825 \\
& RF & 0.953 & 0.943 & 0.850 \\
& 1-NN & 0.938 & 0.932 & 0.832 \\
V.K. 5 5 & 5-NN & 0.945 & 0.935 & 0.840 \\
& SVM & 0.941 & 0.936 & 0.827 \\
& RF & 0.954 & 0.943 & 0.851 \\
& 1-NN & 0.940 & 0.931 & 0.820 \\
V.K. 6 & 5-NN & 0.955 & $\underline{\mathbf{0 . 9 4 6}}$ & 0.865 \\
& SVM & 0.943 & 0.937 & 0.830 \\
& RF & 0.954 & 0.943 & 0.852 \\
\hline
\end{tabular}

$$
\text { Kesinlik }=\frac{T P}{T P+F P}
$$

Duyarlılık, pozitif olarak etiketlenmiş örneklerin gerçekten pozitif olan örneklerin toplam sayısına oranidir.

$$
\text { Duyarlı } l ı k=\frac{T P}{T P+F N}
$$

Kappa değeri, değerlendiriciler arasındaki uyumun istatistiksel ölçüsüdür. Kappa istatistik değerinin 0,6 ile 0,8 arasında olması uyum olduğunu, 0,8 ile 1 arasında olması ise çok iyi bir uyumun olduğunu gösterir. Uyum olmaması durumunda Kappa istatistiği değeri sıfıra eşittir veya sıfırdan küçük olacaktır.

$$
\text { Kappa }=\frac{\text { Gözlenen uyum }- \text { Raslant } 1 \text { sal uyum }}{1-\text { Raslant } 1 \text { sal uyum }}
$$

Tablo 3'deki kappa değerlerinin hepsi 0,8'den büyük olduğundan dolayı bu çalışma için değerlendiriciler arasında çok iyi bir uyum olduğunu söylemek mümkündür. Tabloda yer alan diğer iki değer; duyarlılık ve kesinlik ölçütü birbiriri ile ters orantılıdır. Kesinlik değerlerine baktığımızda ise en yüksek kesinlik değerinin V.K. 2'den elde edilen RF modelinde olduğu görülmektedir. En yüksek duyarlılık değerinin de V.K. 6'dan elde edilen 5-NN modelinde olduğu görülmektedir. $\mathrm{Bu}$ durum, V.K. 2'den elde edilen RF modelinde yanlış pozitif oranının, V.K. 6'dan elde edilen 5-NN modelinde ise yanlıș negatif oranının daha düșük olduğunu göstermektedir. Ayrıca en yüksek kesinlik değerine sahip V.K. 2'den elde edilen RF modelinin Tablo 2'de de en yüksek başarı oranına sahip olduğu görülmektedir.

Çalışmada kullanılan farklı odaklarla çekilmiş 20 katmanlı derinlik görüntüsünün çalışmanın başarısına etkisini göstermek amacıyla Tablo 4, Tablo 5 ve Tablo 6'da farklı veri kümeleri için farklı katman aralıklarının çalıșmada kullanılan sınıflandırma yöntemlerindeki performansı gösterilmektedir. Tablo 4'de eşit sayıda hücre çekirdeği, hücre sitoplazması ve görüntü arka planı örneklerinden oluşan V.K. 1, Tablo 5'de ve Tablo 6'da farklı oranlarda hücre çekirdeği, hücre sitoplazması ve görüntü arka planı örneklerinden oluşan V.K. 2 ve V.K. 3, ayrı ayrı 1-5, 6$10,11-15$ ve $16-20$ arası katmanlardaki yoğunluk değerleri ile 1-NN, 5-NN, SVM ve RF yöntemleri kullanılarak eğitilmiş, elde edilen model tüm görüntüler üzerinde test edilmiştir. Tabloların hiçbirinde elde edilen başarı oranları, alt satırlarında yer alan 20 katmanın birlikte kullanıldığı başarı oranları sonucunu geçememiştir.

Bu sonuçlara göre ilk olarak sınıflandırma yöntemleri ile bölütleme yaklaşımının k-ortalamalar kümeleme yöntemine göre daha iyi bir bölütleme sağladığ görülmektedir. Oluşturulan veri kümelerine baktığımızda sınıflandırma bașarının örnek sayısı 
arttıkça arttığı ve farklı oranlarda hücre çekirdeği, hücre sitoplazması ve görüntü arka planı örneklerinden oluşan veri kümelerinin, eșit sayıda hücre çekirdeği, hücre sitoplazması ve görüntü arka planı örneklerinden oluşan V.K.1'den daha iyi model oluşturduğu görülmüştür. Ayrıca, farklı odaklarla elde edilen görüntülerin bir arada kullanılmasının başarıyı arttırdığı görülmektedir. Bu sonuçlara göre, yeterli sayıda örnekle elde edilen topluluk tabanlı bir yaklaşım olan RF algoritmasının serviks görüntüleri için iyi bir bölütleme yaklaşımı sunduğu görülmektedir. Ayrıca Şekil 4'de örnek test verisinin bir katmanına ait mikroskobik görüntü, Şekil 5 'te ise RF sınıflandırma sonucunda çekirdek, sitoplazma ve arka plan bölütlenmesi yapılmış hali örnek olarak sunulmuştur. Şekil 5'te her piksel ait olduğu sınıfa göre görsel yorumlama açısından renklendirilmiştir.

Tablo 4. Veri Kümesi 1'in farklı katman aralıklarındaki özelliklerinden elde edilen sinıflandırma modellerinin tüm görüntüler üzerindeki test sonuçları

\begin{tabular}{ccccc}
\hline V.K.1. için & 1-NN & 5-NN & SVM & RF \\
\hline $\begin{array}{c}1-5 \text { arası } \\
\text { katmanlar } \\
\text { 6-10 arası }\end{array}$ & $91.06 \%$ & $91.99 \%$ & $91.79 \%$ & $92.32 \%$ \\
katmanlar & $90.13 \%$ & $91.29 \%$ & $91.74 \%$ & $91.74 \%$ \\
$\begin{array}{c}11-15 \text { arası } \\
\text { katmanlar }\end{array}$ & $89.90 \%$ & $90.96 \%$ & $91.67 \%$ & $91.67 \%$ \\
$\begin{array}{c}16-20 \text { arası } \\
\text { katmanlar }\end{array}$ & $89.92 \%$ & $91.48 \%$ & $91.71 \%$ & $91.71 \%$ \\
$\begin{array}{c}\text { Toplam } 20 \\
\text { katman }\end{array}$ & $\mathbf{9 2 . 6 8 \%}$ & $\mathbf{9 3 . 4 3 \%}$ & $\mathbf{9 3 . 2 9 \%}$ & $\mathbf{9 3 . 5 5 \%}$ \\
\hline
\end{tabular}

Tablo 5. Veri Kümesi 2'nin farklı katman aralıklarındaki özelliklerinden elde edilen sinıflandırma modellerinin tüm görüntüler üzerindeki test sonuçları

\begin{tabular}{ccccc}
\hline V.K.2. için & $1-N N$ & $5-N N$ & SVM & RF \\
\hline $\begin{array}{c}1-5 \text { arası } \\
\text { katmanlar }\end{array}$ & $91.13 \%$ & $92.44 \%$ & $92.60 \%$ & $92.58 \%$ \\
$\begin{array}{c}6-10 \text { arası } \\
\text { katmanlar }\end{array}$ & $90.62 \%$ & $92.19 \%$ & $92.21 \%$ & $92.14 \%$ \\
$\begin{array}{c}11-15 \text { arası } \\
\text { katmanlar }\end{array}$ & $90.92 \%$ & $91.50 \%$ & $91.96 \%$ & $91.81 \%$ \\
$\begin{array}{c}16-20 \text { arası } \\
\text { katmanlar }\end{array}$ & $90.71 \%$ & $92.20 \%$ & $92.19 \%$ & $92.28 \%$ \\
$\begin{array}{c}\text { Toplam 20 } \\
\text { katman }\end{array}$ & $\mathbf{9 2 . 7 2 \%}$ & $\mathbf{9 3 . 2 8 \%}$ & $\mathbf{9 3 . 7 0 \%}$ & $\mathbf{9 4 . 3 8 \%}$ \\
\hline
\end{tabular}

Tablo 6. Veri Kümesi 3'ün farklı katman aralıklarındaki özelliklerinden elde edilen sinıflandırma modellerinin tüm görüntüler üzerindeki test sonuçları

\begin{tabular}{ccccc}
\hline V.K.3. için & $1-N N$ & $5-N N$ & SVM & RF \\
\hline $\begin{array}{c}\text { 1-5 arası } \\
\text { katmanlar } \\
\text { 6-10 arası }\end{array}$ & $91.73 \%$ & $92.50 \%$ & $92.68 \%$ & $92.72 \%$ \\
katmanlar & $91.62 \%$ & $92.19 \%$ & $92.21 \%$ & $92.67 \%$ \\
$\begin{array}{c}11-15 \text { arası } \\
\text { katmanlar }\end{array}$ & $90.80 \%$ & $91.55 \%$ & $91.96 \%$ & $91.89 \%$ \\
$\begin{array}{c}16-20 \text { arası } \\
\text { katmanlar }\end{array}$ & $90.91 \%$ & $92.32 \%$ & $92.45 \%$ & $93.28 \%$ \\
$\begin{array}{c}\text { Toplam } 20 \\
\text { katman }\end{array}$ & $\mathbf{9 2 . 8 5 \%}$ & $\mathbf{9 3 . 7 8 \%}$ & $\mathbf{9 3 . 5 0 \%}$ & $\mathbf{9 4 . 1 8 \%}$ \\
\hline
\end{tabular}

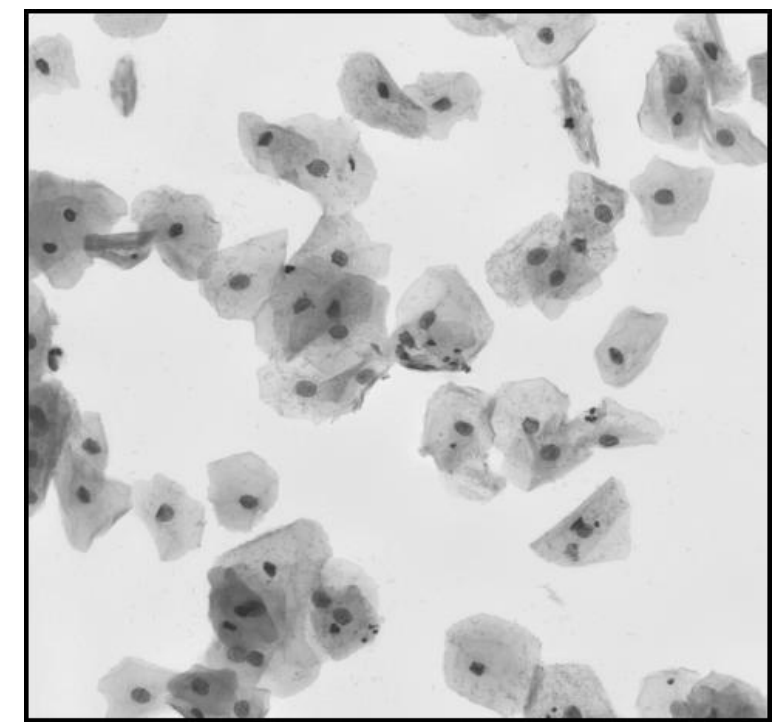

Şekil 4. Örnek test verisinin bir katmanına ait mikroskobik görüntü

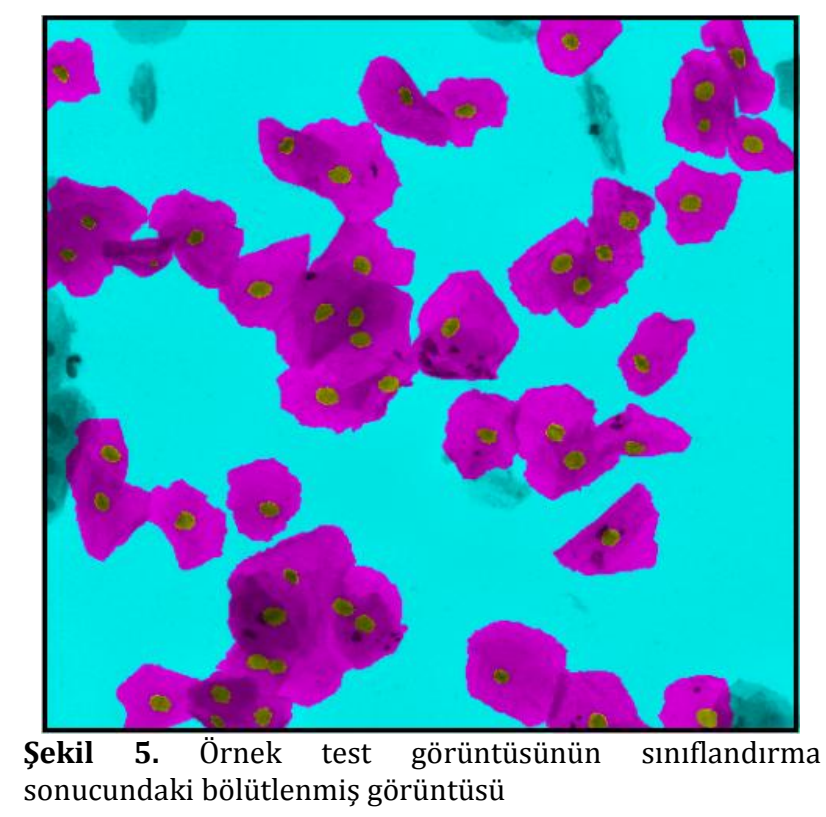

\section{Tartışma ve Sonuç}

Serviks kanseri Pap smear görüntülerinden elde edilen hücrelerin sayısı, șekli ve özelliklerinden teșhis edilir. Bu çalışmada, çok katmanlı ve odaklı servikal sitoloji küplerinde hücre çekirdeği, hücre sitoplazması ve görüntü arka planının bölütlenmesi yapılmış, çalışmanın başarısı test edilmiştir. Sonuçlar, çok katmanlı servikal sitoloji küplerinde çekirdek ve sitoplazma bölütlenmesi için en uygun sınıflandırma yönteminin topluluk öğrenme tabanlı bir yöntem olan rasgele ormanlar, RF, olduğu ve sinıflandırma başarısının eğitim kümesi için seçilen hücre çekirdeği, hücre sitoplazması ve görüntü arka planı örneklerinin sayısına ve oranına bağlı olduğu görülmüștür. İleriki çalıșmalarda, hücrelerin sayısı ve kansere neden olan hücre bozuklukları tespit edilerek çok katmanlı servikal sitoloji görüntülerinden serviks kanserinin otomatik olarak teşhis edilmesi planlanmaktadır. 


\section{Kaynakça}

[1] Longo, D. L. et al. 2011. Harrison's Principles Of Internal Medicine. 18th edition. The McGrawHill, Medical Publishing Division, ABD. 4012s.

[2] T.C. Sağlık Bakanlığı. 1999. Türkiye'de Bölgelere ve Cinsiyete Göre Kanser Olguları. http:// www.saglik.gov.tr/extras/apk2001/092.htm. (Erişim Tarihi: 15.05.2016).

[3] T.C. Sağlık Bakanlığı. 2014. Türkiye Kanser İstatistikleri. http://kanser.gov.tr/Dosya/ca_istatistik/2009kanseraporu.pdf (Erişim Tarihi: 15.05.2016).

[4] World Health Organization. 2016. Human Papillomavirus (HPV) and Cervical Cancer. http://www.who.int/mediacentre/factsheets/fs 380/en/. (Erişim Tarihi: 15.05.2015).

[5] Phoulady, H. A., Goldgof, D. B., Hall, L. O., Mouton, P. R. 2016. A New Approach To Detect and Segment Overlapping Cells in Multi-layer Cervical Cell Volume Images. IEEE 13th International Symposium on Biomedical Imaging, 13-16 Nisan, Prague, Czech Republic, 201-204.

[6] Nosrati, M. S., Hamarneh, G. 2015. Segmentation of Overlapping Cervical Cells: A Variational Method with Star-Shape Prior. IEEE 12th International Symposium on Biomedical Imaging. 16-19 Nisan, New York, USA, 186-189.

[7] Islam, Z., Haque, M. A. 2015. Multi-step Level Set Method for Segmentation of Overlapping Cervical Cells. IEEE International Conference on Telecommunications and Photonics. 26-28 Aralık, Bangladesh, 1-5.

[8] Lakshmi, G. K., Krishnaveni, K. 2014. Multiple Feature Extraction From Cervical Cytology Images by Gaussian Mixture Model. IEEE World Congress on Computing and Communication Technologies, 27 Şubat-1 Mart, Tamilnadu, India, 309-311.

[9] Chuanyun, X., Yang, Z., Sen, W. 2013. Cell Segmentation in Cervical Smear Images Using Polar Coordinates GVF Snake with Radiating Edge Map. Journal of Multimedia, 8(2013), 213219.

[10] Gençtay, A., Aksoy, S., Önder, S. 2012. Unsupervised Segmentation and Classification of Cervical Cell Images. Pattern Recognition, 45(2012), 4151-4168.

[11] Plissiti, M. E., Nikou, C., Charchanti, A. 2011. Automated Detection of Cell Nuclei in Pap Smear Images Using Morphological Reconstruction and Clustering. IEEE Transactions on Information Technology in Biomedicine, 15(2011), 233-241.

[12] Kale, A., Aksoy, S. 2010. Segmentation of Cervical Cell Images. 20th IEEE International Conference on Pattern Recognition, 23-26 Ağustos, İstanbul, Türkiye, 2399-2402.
[13] Song, Y., Cheng, J. Z., Ni, D.,Chen, S., Lei, B., Wang, T. 2016. Segmenting Overlapping Cervical Cell in Pap Smear Images. IEEE 13th International Symposium on Biomedical Imaging, 13-16 Nisan, Prague, Czech Republic, 1159-1162.

[14] Lee, H., Kim, J. 2016. Segmentation of Overlapping Cervical Cells in Microscopic Images with Superpixel Partitioning and Cellwise Contour Refinement. IEEE Conference on Computer Vision and Pattern Recognition Workshops, 27-30 Haziran, Seattle, USA, 63-69.

[15] Zhang, L., Kong, H., Chin, C. T., Liu, S., Chen, Z., Wang, T., \& Chen, S. 2014. Segmentation of Cytoplasm and Nuclei of Abnormal Cells in Cervical Cytology Using Global and Local Graph Cuts. Computerized Medical Imaging and Graphics, 38(5), 369-3.

[16] Yang-Mao, S. F., Chan, Y. K., Chu, Y. P. 2008. Edge Enhancement Nucleus and Cytoplast Contour Detector of Cervical Smear Images. IEEE Transactions on Systems, Man, and Cybernetics, Part B (Cybernetics), 38(2), 353-366.

[17] Lu, Z., Carneiro, G., Bradley, A. P. 2015. An Improved Joint Optimization of Multiple Level Set Functions for the Segmentation of Overlapping Cervical Cells. IEEE Transactions on Image Processing 24(2015), 1261-1272.

[18] Lu, Z., Carneiro, G., Bradley, A. P., Ushizima, D., Nosrati, M. S., Bianchi, A. G. C., Carneiro, C. M., Hamarneh, G. 2016. Evaluation of Three Algorithms for the Segmentation of Overlapping Cervical Cells. IEEE Journal of Biomedical and Health Informatics, Online Publication.

[19] Rao, A. R., Srivinas, V.V. 2006. Regionalization of Watersheds by Fuzzy Cluster Analysis. Journal of Hydrology, 318(1), 57-79.

[20] Franco-Lopez, H., Ek, A. R., Bauer, M. E. 2001. Estimation and Mapping of Forest Stand Density, volume, and Cover Type Using the K-Nearest Neighbors Method. Remote Sensing of Environment 77(3), 251-274.

[21] Vapnik, V. 1998. Statistical Learning Theory, 1st ed., Wiley-Interscience, New York.

[22] Camps-Valls, G., Bruzzone, L. 2005. Kernel-based Methods for Hyperspectral Image Classification. IEEE Trans. Geoscicience and Remote Sensing 43(6), 1351-1362.

[23] Schölkopf, B., Smola, A. J. 2002. Learning with kernels in Support Vector Machines, Regularization, Optimization, and Beyond. Adaptive Computation and Machine Learning, The MIT Press, Cambridge, Massachusetts.

[24] Breiman L. 2001. Random Forests. Machine Learning. 45(1), 5-32.

[25] Pal M. 2005. Random Forest Classifier for Remote Sensing Classification. International Journal Of Remote Sensing, 26(1), 217-222. 